\title{
Performance Criteria for Capture and/or Immobilization Technologies
}

Fuel Cycle Research \& Development

\author{
Prepared for \\ U.S. Department of Energy \\ Materials Recovery and Waste Form \\ Development Campaign \\ R. T. Jubin, S. H. Bruffey (ORNL), \\ D. M. Strachan (Strata-G, LLC) \\ N. R. Soelberg (INL) \\ B. B. Spencer (ORNL), B. J. Riley (PNNL)
}

February 2016 FCRD-MRWFD-2016-000533

INL/EXT-16-38035

ORNL/TM-2016-73 


\section{DISCLAIMER}

This information was prepared as an account of work sponsored by an agency of the U.S. Government. Neither the U.S. Government nor any agency thereof, nor any of their employees, makes any warranty, expressed or implied, or assumes any legal liability or responsibility for the accuracy, completeness, or usefulness, of any information, apparatus, product, or process disclosed, or represents that its use would not infringe privately owned rights. References herein to any specific commercial product, process, or service by trade name, trade mark, manufacturer, or otherwise, does not necessarily constitute or imply its endorsement, recommendation, or favoring by the U.S. Government or any agency thereof. The views and opinions of authors expressed herein do not necessarily state or reflect those of the U.S. Government or any agency thereof. 


\section{SUMMARY}

The capture and subsequent immobilization of the four regulated volatile radionuclides $\left({ }^{3} \mathrm{H},{ }^{14} \mathrm{C},{ }^{85} \mathrm{Kr}\right.$, and ${ }^{129} \mathrm{I}$ ) from the off-gas streams of a used nuclear fuel (UNF) reprocessing facility has been a topic of substantial research interest for the US Department of Energy and its international colleagues. Removal of some or all of these radionuclides (e.g., based upon fuel burnup, fuel type, cooling time) from the plant effluent streams prior to discharge to the environment is required to meet regulations set forth by the US Environmental Protection Agency. Upon removal, the radionuclide, as well as associated sorbents that cannot be cost-effectively regenerated, is destined for conversion to a waste form. Research in separation and capture methodologies has included a wide range of technologies, including liquid caustic scrubbing systems, solid adsorbents, and cryogenic distillation. The studies of waste forms have been correspondingly diverse. In considering the technologies available for future development and implementation of both sorbents and waste forms, it is necessary to identify benchmark measures of performance to evaluate objectively each sorbent system or waste form.

Sets of performance criteria and associated metrics have been developed for sorbent and waste form evaluation. These criteria address physical, radiological, and chemical characteristics, technical practicality, technical maturity, cost, and, for sorbents, system performance. The sets of criteria and associated metrics appear to be sufficiently robust and should be applicable, whether the wastes containing the four volatile radionuclides $\left({ }^{3} \mathrm{H},{ }^{14} \mathrm{C},{ }^{85} \mathrm{Kr}\right.$, and $\left.{ }^{129} \mathrm{I}\right)$ are ultimately classified as low-level or high-level waste. Further, they appear to be sufficient to address both aqueous reprocessing and electrochemical reprocessing of UNF.

These sets of criteria and associated metrics can serve as tools to evaluate performance at multiple stages within the research and development process. It is expected that the evaluation of these criteria and metrics will provide a technically based foundation for the comparison of sorbent and waste form performance for the four volatile radionuclides likely to require capture in a US nuclear fuel reprocessing facility.

Future revisions of this document will develop additional granularity regarding the acceptable values included it the tables of criteria and metrics. 
This page intentionally left blank. 


\section{CONTENTS}

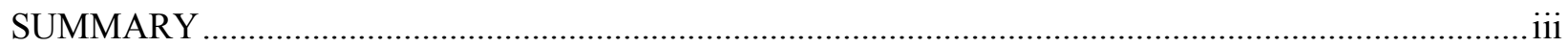

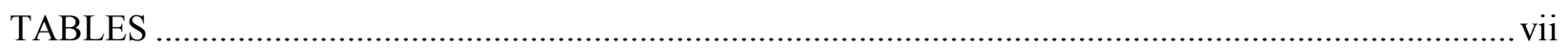

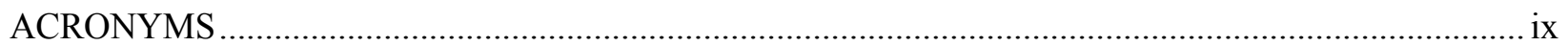

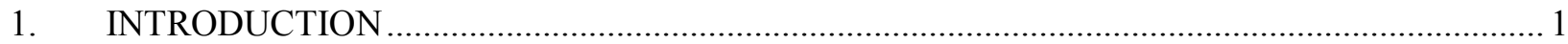

2. REGULATIONS RELATED TO SORBENT AND WASTE FORM PERFORMANCE ............... 2

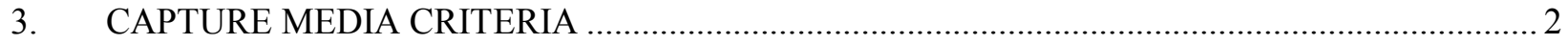

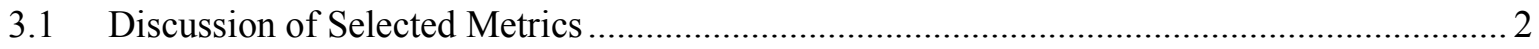

3.2 Additional Notes on Capture Criteria and Metrics for 3H .............................................. 4

3.3 Additional Notes on Capture Criteria and Metrics for ${ }^{14} \mathrm{C}$................................................. 4

3.4 Additional Notes on Capture Criteria and Metrics for ${ }^{85} \mathrm{Kr}$.............................................. 4

3.5 Additional Notes on Capture Criteria and Metrics for ${ }^{129} \mathrm{I}$.............................................. 4

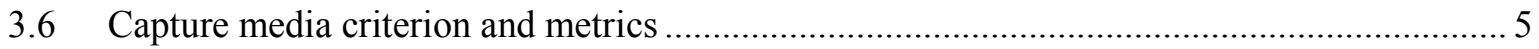

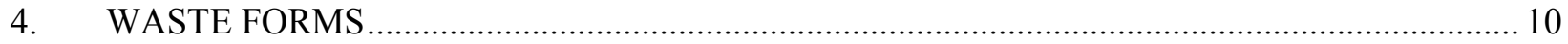

4.1 Impacts of Waste Form Classification and Repository Requirements ................................ 10

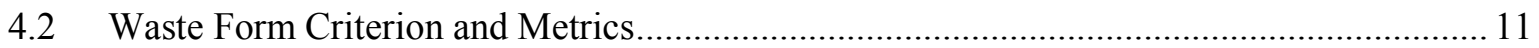

4.3 Additional Notes on Waste Form Criteria and Metrics for ${ }^{129}$ I.......................................... 14

4.4 Additional Notes on Waste Form Criteria and Metrics for ${ }^{85} \mathrm{Kr}$........................................ 14

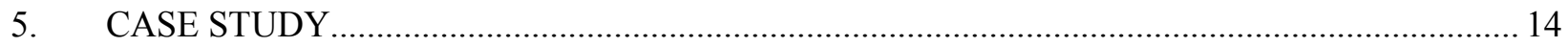

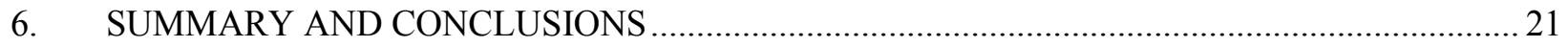

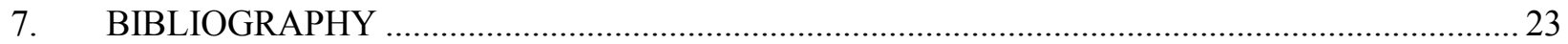


This page intentionally left blank. 


\section{TABLES}

Table 3-1. Target DF values for the volatile radionuclides .................................................................. 3

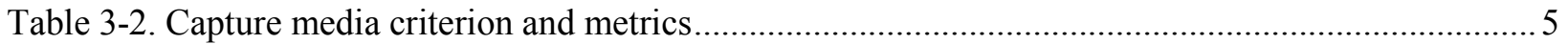

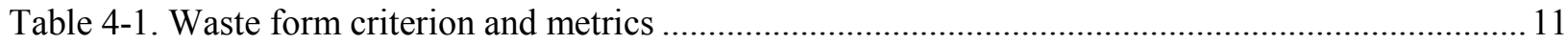

Table 5-1. Metrics for technical performance and physical and chemical characteristics criterion

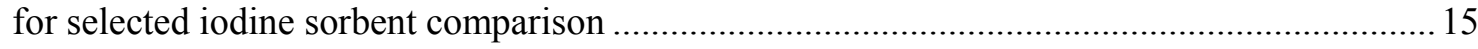

Table 5-2. Metrics for technical practicality criterion for selected iodine sorbent comparison.................. 17

Table 5-3. Metrics for system design and performance criterion for selected iodine sorbent comparison. 18

Table 5-4. Metrics for technical maturity criterion for selected iodine sorbent comparison ..................... 19

Table 5-5. Metrics for cost criterion for selected iodine sorbent comparison. 20 
This page intentionally left blank. 


\section{ACRONYMS}

ANSI

ASTM

BET

DF

EPA

HEPA

IFC

MOX

MSDS

NFPA

TRL

UFC

UNF

UOX

WAC
American National Standards Institute

American Society for Testing and Materials

Brunauer-Emmett-Teller

decontamination factor

Environmental Protection Agency

high-efficiency particle air

International Fire Code

mixed oxide $\left(\mathrm{UO}_{2}-\mathrm{PuO}_{2}\right)$

materials safety data sheet

National Fire Protection Association

technology readiness level

Uniform Fire Code

used nuclear fuel

uranium oxide $\left(\mathrm{UO}_{2}\right)$

waste acceptance criteria 
This page intentionally left blank. 


\section{INTRODUCTION}

The capture and subsequent immobilization of the four regulated volatile radionuclides $\left({ }^{3} \mathrm{H},{ }^{14} \mathrm{C},{ }^{85} \mathrm{Kr}\right.$, and ${ }^{129} \mathrm{I}$ ) from the off-gas streams of a used nuclear fuel (UNF) reprocessing facility has been a topic of substantial research interest for the US Department of Energy DOE and its international colleagues. Removal of some or all of these radionuclides from the plant effluent streams prior to discharge to the environment is required to meet regulations set forth by the US Environmental Protection Agency (EPA). The extent of removal will be dependent upon fuel burnup, fuel type, cooling time, and other related factors. Upon removal, the radionuclide, as well as associated sorbents that cannot be cost-effectively regenerated, is destined for conversion to a waste form. Research in separation and capture methodologies has included a wide range of technologies, including liquid caustic scrubbing systems, solid adsorbents, and cryogenic distillation. The studies of waste forms have been correspondingly diverse. In considering the technologies available for future development and implementation of both sorbents and waste forms, it is necessary to identify benchmark measures of performance to evaluate objectively each sorbent system or waste form.

This document provides initial guidance on the types of performance metrics used to evaluate off-gas capture materials and waste forms intended for use in the recycling of UNF. For capture materials, general performance measures applicable to capture technologies for all four radionuclides are identified first, followed by a discussion of any metrics that may be specific only to a select radionuclide and its capture possibilities, where appropriate.

For waste forms, the performance criteria and metrics are generically identified without any judgement in this document about waste classification as high-level waste or low-level waste, or any presumption about specific transportation, storage, or disposal site waste acceptance criteria (WAC), beyond the following acknowledgements:

- Canister and package size and weight limits should be expected.

- Free liquids, fines, chemical reactivity, thermal, and mechanical stability limits should be expected.

- All release rates shall be controlled to ensure that the dose to the public over time from the released radionuclide must be within dose limits. The actual value(s) will be developed when a repository is selected and a total system performance analysis has been performed.

The focal point of the report is then contained in two main sections addressing criteria relevant to the evaluation of the capture media/systems and waste form performance. Suggested units and desired trends are noted, along with comments regarding the significance of each metric. It is expected that additional granularity with regard to the acceptable ranges of values will be developed and included in future revisions of this document.

Each of the four target radionuclides is unique in its specific activity, decay energy, required decontamination factor (DF), expected types of capture technologies, chemistry, and many other properties. Thus, the relative importance of individual metrics for both sorbents and waste forms may differ based on the specific properties of the radionuclide that the sorbent is designed to capture or the waste form it is designed to immobilize. For example, the selectivity of a sorbent could be of high importance for ${ }^{85} \mathrm{Kr}$, and it could result in a significant increase in waste volume should the sorbent also capture xenon. However, the chemical stability of a ${ }^{85} \mathrm{Kr}$ sorbent is of less importance than other metrics in a reprocessing scheme in which the noble gases are captured after the off-gas stream has been treated and many of the most reactive compounds have been removed. The development of the importance or "value" of each metric within each of the criteria has not been included in this document. However, it may be the subject of a follow-on study that could include an effort to develop not only these relative weighting factors, but also an examination of the relative weight that should be placed on the broader overarching criteria. 


\section{REGULATIONS RELATED TO SORBENT AND WASTE FORM PERFORMANCE}

The processes by which sorbent materials, separation processes, and waste forms are selected must begin with an evaluation of their ability to contribute to regulatory compliance. In the case of sorbent materials and separation processes used to remove the four regulated volatile radionuclides, the regulatory requirements, when applied to a reprocessing facility, result in a range of DF values that depend on the characteristics of the fuel being processed, the processing rate, and other considerations (Jubin et al. 2012a). For waste form materials, the physical and chemical attributes are dictated by what is needed to allow a future candidate repository to meet performance guidelines that have yet to be set by the regulator. Since there is no candidate repository and, hence, the chemical and physical properties for waste forms are largely unknown, our approach is to provide a list of physical and chemical properties that should be an important part of a viable waste form. This list was checked qualitatively against the waste form properties that are currently available for the waste that was destined for the Yucca Mountain repository (DOE 2012). We find that the metrics listed in the tables in this document are consistent with those required for the Yucca Mountain repository, but the properties needed for a viable waste form going to Yucca Mountain are a subset of those shown in the table below. Ultimately, the materials selection process is complex and involves trade-offs between material properties, cost-to-benefit studies, technology readiness assessments (DoD 2011), and so on.

\section{CAPTURE MEDIA CRITERIA}

Five criteria were identified for the capture material and related systems. These are (1) technical performance and characteristics (physical and chemical properties), (2) technical practicality, (3) system design and performance, (4) technical maturity, and (5) cost. In general, these apply to capture materials / systems for all four radionuclides of interest. For each of these five criteria, multiple metrics have been identified which attempt to describe the important aspects of that criterion. Table 3.2 lists the five criteria and the associated metrics. Also included in the table are the preferred reporting units and the preferred trend in a specific metric. General descriptions for each metric also are provided. In a few cases, there is no clear desired trend. Rather, the value for that metric should be evaluated in the context of the specific radionuclide properties and ultimate implications for process design.

The metrics identified in Table 3-2 tend to focus on solid sorbents that lend themselves to use in packed beds. The evaluation of the metrics for the performance of the capture system assumes a properly designed system that optimizes the relevant performance factors to achieve the desired DF.

The system design and performance criterion includes three metrics: pressure drop, DF, and bed volume. Unlike the other four criteria sets in which the values tend to be intrinsic properties of the capture system, the values for these metrics will vary based upon system design. Additionally, they are interrelated and the values contained within this criterion should be judged as a group. For example, the pressure drop over a sorbent bed can be reduced by increasing the diameter of the sorbent column and decreasing the gas velocity of the stream to be treated. Although this would likely not affect the DF there would be a corresponding increase bed volume. An ideal capture system would be designed to optimize all three metrics.

\subsection{Discussion of Selected Metrics}

In Tables 3-2 and 4-1, there are several metrics that merit a level of discussion that is not contained within the tables. These items are marked with an asterisk $\left(^{*}\right)$ in the tables.

Mechanical Stability - This property is a measure of the attrition of the sorbent material or dust generation during use. Air passing through the packed column causes movement of the particles and subsequent dust generation. The objective is to make sure that the material does not generate a quantity of dust that could cause the bed to decrease significantly in mass as a function of time; to generate fines in 
sufficient quantity to plug high-efficiency particulate air (HEPA) filters; or to cause other conditions, such as excessive dispersion of captured radionuclides or the potential for dust explosions (for combustible dusts). Concentration limits in air for combustible dusts are taken from a report by the US Chemical Safety and Hazard Investigation Board (USCSHIB 2006). Reports and standards from the National Fire Protection Association (NFPA 2015) and the Occupational Safety and Health Administration (OSHA 2005) also are cited as supporting documentation.

Chemical Stability-This metric specifically addresses the impacts of chemical species other than the target species. It is assumed that the sorbent is not adversely impacted by the species it is intended to capture.

Regeneration-The desired properties of the sorbents, e.g., high capacity and selectivity, usually degrade with each regeneration cycle. While there is no theoretical limit on how far these properties should be allowed to degrade with each regeneration cycle, limiting degradation to a level that does not markedly worsen plant operation is prudent. A degradation of the desired properties to $80 \%$ of their starting values is being set in this evaluation as a minimum acceptable value for this metric.

Decontamination Factor-The DF is a measure of the separation of the target radionuclide from the offgas stream and other competing components in the off-gas stream under selected operating parameters. It is defined as the flowrate of the isotope in the gas stream entering the capture system, divided by the flowrate of the isotope in the effluent gas stream. When there is negligible change in the inlet and effluent gas flowrates, the DF can be defined as the concentration of the isotope in the inlet gas stream ([isotope $]_{a}$ ) divided by the concentration of the isotope in the effluent gas stream ([isotope $]_{b}$ ). Current US federal regulations for the release of gaseous radionuclides from the nuclear fuel cycle and the resultant estimated radiation doses to the public (EPA 2010; NRC 2012) were used by Jubin et al (2012a) to determine a set of target DFs for a case study of nuclear fuel reprocessing facilities. These results are summarized in Table 3-1. Further discussion of the required DF values for a reprocessing facility is outside the scope of this document. The reader is directed to a series of documents in which this topic is discussed more extensively (Jubin et al. 2011, 2012a; Jubin et al. 2012b; Jubin et al. 2014). Values for the DF depend on the scenario and can range from 1 for ${ }^{3} \mathrm{H}$ and ${ }^{85} \mathrm{Kr}$, i.e. no abatement required after sufficient cooling of the fuel, to about 8,000 for ${ }^{129} \mathrm{I}$, which is independent of fuel age.

Table 3-1. Target DF values for the volatile radionuclides

\begin{tabular}{|c|c|}
\hline Nuclide & DF range \\
\hline${ }^{3} \mathbf{H}$ & $1-700$ \\
\hline${ }^{\mathbf{1 4}} \mathbf{C}$ & $1-30$ \\
\hline${ }^{\mathbf{8 5}} \mathbf{K r}$ & $1-70$ \\
\hline${ }^{\mathbf{1 2 9}} \mathbf{I}$ & $1,000-8,000$ \\
\hline
\end{tabular}

Co-adsorbed Species-There are "tramp" elements and isotopes that can compete for the same sorption sites as the target radionuclide, e.g. ${ }^{12} \mathrm{C}$ competes with ${ }^{14} \mathrm{C}$, and chlorine competes with ${ }^{129} \mathrm{I}$. In some cases, the tramp element forms a thermodynamically more stable compound than the target radionuclide. For some elements, it is impractical to remove or reduce their concentrations without affecting the target radionuclides, e.g. ${ }^{12} \mathrm{C}$ and ${ }^{14} \mathrm{C}$ in $\mathrm{CO}_{2}$, and ${ }^{127} \mathrm{I}$ and ${ }^{129} \mathrm{I}$ cannot be separated except by isotopic separation techniques. In other cases, co-adsorption can be limited by careful process design. This metric is measured by the mol of each co-adsorbed isotope(s) or element(s) per kilogram of sorbent. For example, if the target species is tritium, but the sorbent also co-adsorbs iodine and $\mathrm{CO}_{2}$, this metric would be the ( $\mathrm{mol} \mathrm{I}$ and $\left.\mathrm{mol} \mathrm{CO}_{2}\right) / \mathrm{kg}$ of sorbent. It is desired that the value of this metric be minimized both in terms of the number of species contained within the term and in the total moles of the non-target species adsorbed. 
Flexibility and Pretreatment-The process used to remove the target radionuclide from the off-gas should have a broad operating range to avoid limiting plant throughput through an excessively narrow operating envelope. The operating ranges for such parameters as radionuclide concentration, gas temperature, gas velocity, and other related factors should be as wide as is practicable. Flexibility also refers to the ability of the sorbent to withstand reactive gas phase chemical compounds without significant degradation of its sorption properties.

The concept of gas pretreatment prior to the capture technology is related closely to sorbent flexibility. The less flexible the technology, the greater the likelihood that the gas stream will have to be adjusted before radionuclide removal. There is precedent for the addition of pretreatment steps and other unit operations within capture technologies, but these will increase radionuclide removal costs. Such unit operations also are considered within the process complexity metric, although process complexity takes into account all unit operations, not just those associated with pretreatment.

\subsection{Additional Notes on Capture Criteria and Metrics for ${ }^{3} \mathbf{H}$}

Co-adsorption of ${ }^{129} \mathrm{I}$ should be reduced to the extent possible. Co-adsorption of $\mathrm{H}_{2} \mathrm{O}$ from the air must also be considered as part of total system capacity.

\subsection{Additional Notes on Capture Criteria and Metrics for ${ }^{14} \mathrm{C}$}

It is likely that if ${ }^{14} \mathrm{C}$ is to be abated, the use of a scrubber system could also be considered. Co-adsorption of ${ }^{12} \mathrm{CO}_{2}$ from the air must be considered as part of total system capacity.

\subsection{Additional Notes on Capture Criteria and Metrics for ${ }^{85} \mathrm{Kr}$}

Other technologies such as cryogenic distillation are also possible for the capture of ${ }^{85} \mathrm{Kr}$. Co-adsorption and separation of xenon from the off-gas stream must be considered as part of total system capacity.

\subsection{Additional Notes on Capture Criteria and Metrics for ${ }^{129} \mathrm{I}$}

Other types of iodine capture systems that could be considered include various scrubber systems. 


\subsection{Capture Media Criteria and Metrics}

Table 3-2. Capture media criteria and metrics

\begin{tabular}{|c|c|c|c|}
\hline Property & Unit & Desired trend & Comments \\
\hline \multicolumn{4}{|c|}{ Metrics for technical performance and physical and chemical characteristics criterion } \\
\hline Capacity & Moles $/ \mathrm{m}^{3}$ & High & $\begin{array}{l}\text { The capacity of the bulk material for the radionuclide of interest. Capacity and bulk } \\
\text { density influence sorbent column size }\end{array}$ \\
\hline Selectivity & $\begin{array}{c}\left(\mathrm{X}_{\mathrm{a}} / \mathrm{Y}_{\mathrm{a}}\right) /\left(\mathrm{X}_{\mathrm{b}} / \mathrm{Y}_{\mathrm{b}}\right) \\
\text { (unitless) } \\
\\
\text { Where } X_{a} \text { and } X_{b} \text { are mol } \\
\text { fractions of species } a \text { and } b \\
\text { respectively in the } \\
\text { adsorbed phase, and } Y_{a} \\
\text { and } Y_{b} \text { are mol fractions of } \\
\text { species a and b in the bulk } \\
\text { phase. }\end{array}$ & High & $\begin{array}{l}\text { The extent to which the target element is concentrated in the capture system relative to } \\
\text { non-targeted elements. It influences how much preprocessing of the incoming off-gas } \\
\text { stream must be done to make the material practicable. It also dictates how much post- } \\
\text { processing may be required to separate isotopes that should not be mixed, e.g. }{ }^{3} \mathrm{H} \text { and }{ }^{129} \mathrm{I} \text {, } \\
\text { before conversion to a final waste form }\end{array}$ \\
\hline Particle density & $\mathrm{kg} / \mathrm{m}^{3}$ & High & $\begin{array}{l}\text { Particle density is the density of the sorbent media and included internal pore volume. } \\
\text { This is in contrast to the bulk density that is the average density of the sorbent bed taking } \\
\text { into account the inter-particle void volume. Density, along with capacity, influences } \\
\text { sorbent column size. There is a balance between the density and the permeability of the } \\
\text { sorbent bed that should be considered and may set an upper density limit. High densities } \\
\text { can negatively affect the sorption kinetics of the target element on the sorbent. }\end{array}$ \\
\hline Surface area & $\mathrm{m}^{2} / \mathrm{g}$ & High & $\begin{array}{l}\text { Increased surface area can promote the efficiency of the sorbent. This is not the geometric } \\
\text { surface area of the particles, but the gas active surface area, as likely measured by the } \\
\text { Brunauer-Emmett-Teller (BET) method }\end{array}$ \\
\hline $\begin{array}{l}\text { Specific heat } \\
\text { capacity }\end{array}$ & $\mathrm{J} /(\mathrm{K} \cdot \mathrm{kg})$ or $\mathrm{J} /\left(\mathrm{K} \cdot \mathrm{m}^{3}\right)$ & $\begin{array}{c}\text { Application } \\
\text { dependent }\end{array}$ & $\begin{array}{l}\text { In use, as sorbates load onto the sorbent, the heat of reaction can cause the temperature of } \\
\text { the sorbent to rise. Heat capacity can mitigate this rise. It also affects the time required to } \\
\text { preheat or cool a sorbent column and so may have implications for process design }\end{array}$ \\
\hline $\begin{array}{l}\text { Thermal } \\
\text { conductivity }\end{array}$ & $\mathrm{W} /(\mathrm{m} \cdot \mathrm{K})$ & High & $\begin{array}{l}\text { The thermal conductivity should be sufficiently high that the heat of reaction or decay can } \\
\text { be dissipated sufficiently to maintain a desired bed temperature and to avoid significant } \\
\text { thermal gradients within the sorbent bed. This is a key property for the design and size of } \\
\text { systems that need to be heated or cooled }\end{array}$ \\
\hline Radiation stability & $\begin{array}{l}\% \text { degradation in capacity } \\
\text { over time as a function of } \\
\text { radiation exposure }\end{array}$ & $\begin{array}{l}\text { High stability; } \\
\text { low degradation } \\
\text { over time }\end{array}$ & $\begin{array}{l}\text { Intense background radiation and radioactive sorbates can cause substantial damage to the } \\
\text { sorbent, especially those isotopes with high specific activity }\left({ }^{3} \mathrm{H} \text { and }{ }^{85} \mathrm{Kr}\right) \text {. This can affect } \\
\text { basic sorbent properties (such as capacity, selectivity) and sorbent lifetime }\end{array}$ \\
\hline
\end{tabular}


Performance Criteria for Capture and/or Immobilization Technologies

February 29, 2016 
Table 3-2. (continued)

\begin{tabular}{|c|c|c|c|}
\hline Property & Unit & Desired trend & Comments \\
\hline $\begin{array}{c}\text { Mechanical } \\
\text { stability* }\end{array}$ & $\begin{array}{l}\text { Generated fines }<420 \mu \mathrm{m} \\
\text { with losses to the off-gas } \\
\text { stream of }<50 \mu \mathrm{g} / \mathrm{m}^{3}\end{array}$ & $\begin{array}{l}\text { High stability; } \\
\text { low fines } \\
\text { generation }\end{array}$ & $\begin{array}{l}\text { High gas velocities, chemical reactions, and other plant variables can cause the bed } \\
\text { packing to vibrate and cause some attrition of the particles that make up the bed. Attrition } \\
\text { can yield fine airborne particles that may affect downstream processes, cause premature } \\
\text { failure of the HEPA filters, and, perhaps, affect facility DF. The ability to limit these } \\
\text { losses is reflected by a particle's mechanical stability }\end{array}$ \\
\hline Thermal stability & $\begin{array}{l}\% \text { degradation in capacity } \\
\text { over time at selected } \\
\text { operating temperature }\end{array}$ & $\begin{array}{l}\text { High stability; } \\
\text { low degradation } \\
\text { over time }\end{array}$ & $\begin{array}{l}\text { Thermal stability over both the normal operating and process upset condition temperature } \\
\text { ranges is necessary }\end{array}$ \\
\hline Chemical stability* & $\begin{array}{c}\text { \% degradation in capacity } \\
\text { over time as a function of } \\
\text { other species present in gas } \\
\text { stream }\end{array}$ & $\begin{array}{l}\text { High stability; } \\
\text { low degradation } \\
\text { over time }\end{array}$ & Impacts the operating life and performance of the sorbent \\
\hline Reactivity & $\begin{array}{l}\text { Compatibility as } \\
\text { determined by standardized } \\
\text { compatibility tables }\end{array}$ & $\begin{array}{l}\text { Demonstrated } \\
\text { compatibility } \\
\text { with all } \\
\text { components of } \\
\text { gas stream and } \\
\text { materials of } \\
\text { construction }\end{array}$ & $\begin{array}{l}\text { A measure of the interaction between the sorbent and materials of construction and other } \\
\text { gas stream components }\end{array}$ \\
\hline \multicolumn{4}{|c|}{ Metrics for technical practicality criterion } \\
\hline Regeneration* & $\begin{array}{l}\text { No. of cycles before } \\
\text { degrading to } 80 \% \text { of } \\
\text { capacity for the target } \\
\text { element }\end{array}$ & High & $\begin{array}{l}\text { This property affects the overall plant design and cost of operation. Some materials may } \\
\text { not be regenerated, i.e., they are single use }\end{array}$ \\
\hline Bulk density & $\mathrm{kg} / \mathrm{m}^{3}$ & High & $\begin{array}{l}\text { Bulk density is the average density of the sorbent bed taking into account the particle } \\
\text { density and the intra-particle void volume, i.e., the mass of the sorbent }(\mathrm{kg}) \text { divided by the } \\
\text { volume of the packed bed }\left(\mathrm{m}^{3}\right) \text {. Bulk density impacts bed size, pressure drop, and surface } \\
\text { area available for reaction. Increases in bulk density approaching the particle density in } \\
\text { the limiting case will result in the smallest bed size but excessive pressure drop }\end{array}$ \\
\hline $\begin{array}{c}\text { Co-adsorbed } \\
\text { species* }\end{array}$ & Moles $/ \mathrm{kg}$ & $\begin{array}{l}\text { Small in } \\
\text { number of } \\
\text { species and } \\
\text { quantity }\end{array}$ & $\begin{array}{l}\text { Indicates how much the overall capacity of the sorbent is affected by sorption of non- } \\
\text { targeted elements. Tramp elements or isotopes, e.g., } \mathrm{Cl},{ }^{12} \mathrm{C}, \mathrm{Xe} \text {, and so on, fall into this } \\
\text { category }\end{array}$ \\
\hline
\end{tabular}


Table 3-2. (continued)

\begin{tabular}{|c|c|c|c|}
\hline Property & Unit & Desired trend & Comments \\
\hline Robustness & $\begin{array}{l}\% \text { variation in operating } \\
\text { parameters tolerated } \\
\text { without deleterious effects }\end{array}$ & High & Tolerance to process upset conditions \\
\hline $\begin{array}{l}\text { Flexibility and } \\
\text { pretreatment* }\end{array}$ & $\begin{array}{l}\text { Operating ranges; no. of } \\
\text { unit operations for } \\
\text { pretreatment }\end{array}$ & $\begin{array}{c}\text { High flexibility; } \\
\text { minimal } \\
\text { pretreatment }\end{array}$ & The width of the sorbent standard operating envelope \\
\hline Process complexity & $\begin{array}{c}\text { Number and type of control } \\
\text { systems and unit operations } \\
\text { required. }\end{array}$ & Low & Affects the cost, volume, and footprint of the treatment system \\
\hline Energy consumption & $\mathrm{kW} / \mathrm{mole}$ & Low & This is the energy required to effect separation of the target element \\
\hline $\begin{array}{l}\text { Environmental } \\
\text { safety and health }\end{array}$ & $\begin{array}{l}\text { Classification according to } \\
\text { National Fire Protection } \\
\text { Association ratings }\end{array}$ & Low & $\begin{array}{l}\text { Other applicable hazard classification systems may be used as appropriate [e.g., materials } \\
\text { safety data sheet (MSDS), ASTM, Uniform Fire Code (UFC), International Fire Code } \\
\text { (IFC), ANSI, and local and state codes] }\end{array}$ \\
\hline \multicolumn{4}{|c|}{ Metrics for system design and performance criterion } \\
\hline Pressure drop & $\mathrm{Pa} / \mathrm{m}$ & Low & $\begin{array}{l}\text { Pressure drop should be minimal to avoid operational difficulties. This value is affected } \\
\text { by sorbent densities and bed size }\end{array}$ \\
\hline $\begin{array}{l}\text { Decontamination } \\
\text { factor (DF)* }\end{array}$ & $\begin{array}{l}{[\text { Isotope }]_{a} /[\text { Isotope }]_{b}} \\
\quad \text { (Unitless) }\end{array}$ & High & Regulatory requirements dictate the value for specific isotopes \\
\hline Bed volume & $\mathrm{m}^{3}$ & Low & $\begin{array}{l}\text { Bed volume is a function of the capacity, particle density, and bulk density of the sorbent } \\
\text { material }\end{array}$ \\
\hline \multicolumn{4}{|c|}{ Metrics for technical maturity criterion } \\
\hline $\begin{array}{l}\text { Technology } \\
\text { readiness level of } \\
\text { sorbent system }\end{array}$ & $1-9$ & High & $\begin{array}{l}\text { The technology readiness level is defined in the technology readiness assessment report } \\
\text { (DoD 2011) }\end{array}$ \\
\hline $\begin{array}{l}\text { Commercial } \\
\text { availability }\end{array}$ & Yes / No & $\begin{array}{c}\text { Readily } \\
\text { available }\end{array}$ & $\begin{array}{l}\text { Commercial availability of the sorbent is an important parameter because of the cost of } \\
\text { producing a material "in house." However, some sorbents can be made in place, such as a } \\
\mathrm{AgNO}_{3} \text { solution on an inert substrate, e.g., } \mathrm{Al}_{2} \mathrm{O}_{3} \text {. Commercial availability eliminates the } \\
\text { need to build infrastructure and accrues the benefit of scale because material is made for a } \\
\text { number of customers }\end{array}$ \\
\hline $\begin{array}{c}\text { Time to } \\
\text { commercialization }\end{array}$ & $\mathrm{y}$ & Short & This must be compatible with the construction of the reprocessing facility \\
\hline
\end{tabular}


Performance Criteria for Capture and/or Immobilization Technologies

Table 3-2. (continued)

\begin{tabular}{|c|c|c|l|}
\hline Property & Unit & Desired trend & \multicolumn{2}{|c|}{ Comments } \\
\hline \multicolumn{3}{|c|}{ Metrics for cost criterion } \\
\hline $\begin{array}{c}\text { Cost of sorbent } \\
\text { material }\end{array}$ & $\$ / \mathrm{kg}, \$ / \mathrm{Ci}$, or $\$ /$ mole & Low & Cost of sorbent and any associated consumable materials \\
\hline Operating cost & $\$ /$ curie & Low & Cost to operate the capture system \\
\hline
\end{tabular}




\section{WASTE FORMS}

Four criteria were identified for waste forms. These are (1) technical performance and characteristics (physical and chemical properties), (2) technical practicality, (3) technical maturity, and 4) cost. For each of these four criteria, multiple metrics have been identified which attempt to describe the important aspects of that criterion. Table 4.1 lists the four criteria and the associated metrics. As discussed below, establishing desired values for the waste form metrics is problematic because a geologic repository has not been identified. Nevertheless, most metrics are independent of such considerations (i.e. physical, radiological, and chemical durability), or the metrics can be evaluated based on an assumed environment. Other metrics may be required or may need to be revised as progress is made toward the ultimate selection of a disposition pathway.

\subsection{Impacts of Waste Form Classification and Repository Requirements}

Currently, there is no US candidate repository for high-level nuclear waste and no waste acceptance requirements. Hence, this document attempts to identify the criteria and associated metrics that could be used to select waste forms for the volatile radionuclides. The list of metrics compared favorably with those found in the performance specifications for the proposed Yucca Mountain repository (DOE 2012); i.e, the Yucca Mountain list was a subset of the list of metrics shown in Table 4.1.

As noted in the introduction, the development of the importance or "value" of each metric within each of the criteria has not been included in this document. For the capture metrics and criteria, it is anticipated that the weighting factors for individual metrics may vary with the target isotope. In the case of the criteria and metrics for waste forms, the weighting of the individual metrics and the criteria are expected to be influenced by the specific repository conditions and the waste classification, as well as the specific isotope. For example, the classification of the waste as high-level, low-level, or greater than class $\mathrm{C}$ could change the relative importance of a specific criterion. Thus, on a scale of 1 to 10 , criterion A might be considered a 4 (moderate importance) if the waste is classified as low-level, but an 8 (relatively high importance) if the waste is classified as high-level. In comparing the performance metrics of two waste forms, it is also critical that these materials be compared with the same repository conditions; i.e., oxidizing or reducing. 


\subsection{Waste Form Criteria and Metrics}

Table 4-1. Waste form criterion and metrics

\begin{tabular}{|c|c|c|c|}
\hline Property & Unit & Desired Trend & Comments \\
\hline \multicolumn{4}{|c|}{ Metrics for technical performance and physical and chemical characteristics criterion } \\
\hline $\begin{array}{l}\text { Target element } \\
\text { concentration }\end{array}$ & $\mathrm{mol} / \mathrm{kg}$ & High & $\begin{array}{l}\text { This dictates the amount of waste form that must be made to contain the target } \\
\text { radionuclide inventory (moles of isotope per unit mas of the waste form). It impacts total } \\
\text { waste form volume, thermal load, curie content, and radiation levels for the containers. } \\
\text { This property is based on the elemental concentration of the target species and does not } \\
\text { include tramp elements }\end{array}$ \\
\hline Density & $\mathrm{kg} / \mathrm{m}^{3}$ & High & $\begin{array}{l}\text { The waste form density could be required to determine the size and dimension limits for } \\
\text { the waste container or package, and is one of the factors that could determine the volume } \\
\text { that the waste form occupies during storage, transportation, or disposal }\end{array}$ \\
\hline Heat capacity & $\mathrm{J} /(\mathrm{K} \cdot \mathrm{kg})$ or $\mathrm{J} /\left(\mathrm{K} \cdot \mathrm{m}^{3}\right)$ & Low & $\begin{array}{l}\text { Heat capacity controls heating and cooling rates of the waste form when coupled with the } \\
\text { heat transfer conditions }\end{array}$ \\
\hline Thermal conductivity & $\mathrm{W} /(\mathrm{m} \cdot \mathrm{K})$ & High & $\begin{array}{l}\text { A waste form is heated in two ways - decay heat and co-disposed waste. The waste form } \\
\text { must not suffer deleterious property changes because of this heating (see "thermal } \\
\text { limits"). Additionally, it is likely that specifications in the waste acceptance criteria will } \\
\text { limit the surface temperature and total thermal power of a container }\end{array}$ \\
\hline $\begin{array}{l}\text { Mechanical } \\
\text { properties }\end{array}$ & $\%$ fines produced & $\begin{array}{l}\text { Less than } \\
0.01 \% \text { fines } \\
\text { formation }\end{array}$ & $\begin{array}{l}\text { Dust generation during storage, transport, or disposal, which could be caused by } \\
\text { chemical, physical, or thermal changes, should be within expected fines limits }\end{array}$ \\
\hline Chemical properties & $\begin{array}{l}\text { Classification according to } \\
\text { National Fire Protection } \\
\text { Association ratings }\end{array}$ & Low & $\begin{array}{l}\text { Waste forms that display combustibility, are strong oxidizers, undergo rapid } \\
\text { decomposition, or could have other chemical reactions should be avoided. Included in this } \\
\text { metric is the toxicity of the waste form. If the current EPA regulations concerning } \\
\text { hazardous waste apply, the waste form must pass the Toxicity Characteristic Leaching } \\
\text { Procedure published by the EPA }\end{array}$ \\
\hline $\begin{array}{l}\text { Dissolution or release } \\
\text { rate }\end{array}$ & 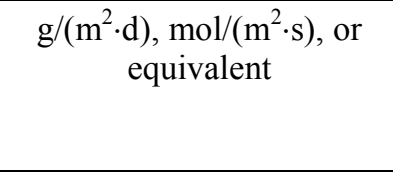 & Low & $\begin{array}{l}\text { Upon failure of any applicable engineered barriers, the dose to the public over time from } \\
\text { the released radionuclide must be within dose limits. The metric values should be isotope } \\
\text { specific; i.e., for iodine, a value such as "less than that for AgI under same redox } \\
\text { conditions" might be selected }\end{array}$ \\
\hline Thermal limits & ${ }^{\circ} \mathrm{C}$ & High & $\begin{array}{l}\text { Identify an upper temperature limit to prevent excessive property changes in waste form. } \\
\text { A waste form is heated in two ways-internal decay heat and heat from co-disposed } \\
\text { waste. The waste form must not suffer deleterious property changes as a result of this } \\
\text { heating }\end{array}$ \\
\hline
\end{tabular}


Table 4-1. (continued)

\begin{tabular}{|c|c|c|c|}
\hline Property & Unit & Desired Trend & Comments \\
\hline $\begin{array}{l}\text { Waste form canister } \\
\text { interactions }\end{array}$ & $\begin{array}{l}\% \text { alteration of canister or } \\
\text { waste form as a function of } \\
\text { time }\end{array}$ & Minimal & $\begin{array}{l}\text { The waste form properties cannot be significantly degraded by interaction between the } \\
\text { waste form and the engineered barrier materials }\end{array}$ \\
\hline Radiation effects & $\begin{array}{l}\% \text { increase in radionuclide } \\
\text { release rate per Gy }\end{array}$ & High & $\begin{array}{l}\text { Identify the maximum dose that the waste form can tolerate. Waste forms must be robust } \\
\text { with respect to potential external radiation fields and self-irradiation from the } \\
\text { immobilized isotopes. Additionally, as the immobilized isotope decays, a new chemistry } \\
\text { evolves. The waste form properties cannot degrade significantly such that the repository } \\
\text { performance is compromised }\end{array}$ \\
\hline \multicolumn{4}{|c|}{ Metrics for technical practicality criterion } \\
\hline Process complexity & $\begin{array}{l}\text { Number of control systems } \\
\text { and unit operations } \\
\text { required }\end{array}$ & Low & $\begin{array}{l}\text { Process complexity plays an important role in the viability of a waste form process. } \\
\text { Complex processes might be more difficult to operate and maintain remotely }\end{array}$ \\
\hline Robustness & $\begin{array}{l}\text { Maximum \% variation in } \\
\text { waste form properties } \\
\text { without deleterious effects }\end{array}$ & High & $\begin{array}{l}\text { Waste forms that can tolerate wider allowable ranges in properties and still meet waste } \\
\text { form performance requirements are preferred. Although process upsets are anticipated, } \\
\text { the effect that these have on the overall product should be minimal }\end{array}$ \\
\hline $\begin{array}{l}\text { Tolerance to tramp } \\
\text { elements }\end{array}$ & $\begin{array}{l}\text { Mol/kg that can be } \\
\text { included without } \\
\text { deleterious effects }\end{array}$ & High & $\begin{array}{l}\text { During the reprocessing of fuel, tramp elements with similar chemistry to the target } \\
\text { radionuclide may be captured and immobilized in the waste form. It will be important to } \\
\text { understand their effect on the waste form properties and on the performance of the waste } \\
\text { form in a storage facility or repository }\end{array}$ \\
\hline Waste pretreatment & $\begin{array}{l}\text { Number of unit operations } \\
\text { required to prepare loaded } \\
\text { sorbent for waste form } \\
\text { production process }\end{array}$ & Minimal & $\begin{array}{l}\text { Ideally, the sorbent can be regenerated, leading to a simple waste stream that can be } \\
\text { efficiently processed to a final waste form }\end{array}$ \\
\hline Energy consumption & $\mathrm{kW} /$ mole & Low & $\begin{array}{l}\text { This is a measure of the amount of energy that is required to covert the captured } \\
\text { radionuclide to a final waste form. This considers only the energy consumed within the } \\
\text { waste treatment facility and not the energy used in producing the materials consumed }\end{array}$ \\
\hline \multicolumn{4}{|c|}{ Metrics for technical maturity criterion } \\
\hline $\begin{array}{l}\text { Technology readiness } \\
\text { level }\end{array}$ & $1-9$ & High & $\begin{array}{l}\text { The technology readiness level is defined in the technology readiness assessment report } \\
\text { (DoD 2011). }\end{array}$ \\
\hline $\begin{array}{l}\text { Commercial } \\
\text { availability }\end{array}$ & Yes / No & Available & $\begin{array}{l}\text { This can include the commercial availability of a process or of the precursor materials } \\
\text { required for waste form manufacture }\end{array}$ \\
\hline $\begin{array}{l}\text { Time to } \\
\text { commercialization }\end{array}$ & $\mathrm{y}$ & Short & Must be compatible with the time scale of the reprocessing facility \\
\hline
\end{tabular}


Performance Criteria for Capture and/or Immobilization Technologies

February 29, 2016

Table 4-1. (continued)

\begin{tabular}{|c|c|c|l|}
\hline Property & Unit & Desired Trend & Comments \\
\hline \multicolumn{4}{|c|}{ Metrics for cost criterion } \\
\hline Cost of materials & $\$ / \mathrm{kg}$ & Low & Cost of consumable materials \\
\hline Operating cost & $\$ /$ curie & Low & Processing cost less consumables \\
\hline
\end{tabular}




\subsection{Additional Notes on Waste Form Criteria and Metrics for ${ }^{129} \mathrm{I}$}

A current review of available iodine waste forms is available in Riley 2016. One of the most important metrics for waste form performance is dissolution rate. In the case of iodine, since many iodine capture materials capture iodine as AgI, it would be logical to assume that any iodine release rate from a waste form should be lower than that of AgI under expected repository conditions. In testing of potential waste forms, AgI should be included as a reference point, as it could represent the direct disposal of the iodineloaded sorbent.

\subsection{Additional Notes on Waste Form Criteria and Metrics for ${ }^{85} \mathrm{Kr}$}

Of the four volatile radionuclides, krypton is unique because it is an inert gas at room temperature.

Therefore, there are limited options for converting it to a waste form on which traditional waste form tests can be used. The tabulated metrics for waste forms may need to be interpreted with the understanding that krypton is likely to be stored as a gas in pressurized containers that may or may not contain a filler, e.g., a metal organic framework material or zeolite, that allows more gas to be stored in a container than could be stored in an otherwise empty container at the same pressure. An option is to co-deposit krypton with a metal on the inside of steel containers, thereby locking the krypton in a metal matrix. There have been several studies of the immobilization or encapsulation of xenon or krypton in zeolites (Christensen et al. 1982; Christensen et al. 1983; Kopelevich and Chang 2001; Lim et al. 2001; Miyake et al. 1984; Penzhorn 1981; Penzhorn and Mertin 1984; Penzhorn et al. 1984; Penzhorn et al. 1982; Penzhorn et al. 1980; Seoung et al. 2014; Whitmell et al. 1987). These solid phases could be studied with traditional waste form tests; and hence, the metrics for the immobilization solids for the other volatile radionuclides would be important for the krypton immobilization solids.

\section{CASE STUDY}

The selective removal of iodine from an off-gas stream can be performed in many ways. To illustrate the use of the criteria and metrics provided in Section 3, iodine removal by $\mathrm{AgNO}_{3}$-coated Berl saddles is compared with iodine removal by silver-exchanged faujasite (Tables 5-1 through 5-5). These two technologies have both been implemented at engineering scale, which will assist in provision of the information required by the evaluation metric.

$\mathrm{AgNO}_{3}$-coated Berl saddles were used in the T and B Plants of the Hanford, Washington, facility in the 1950s to limit ${ }^{131}$ I release to the atmosphere (Cederberg et. al. 1961; O’Brien et. al. 1963; Paas et. al. 1951; McNabney and Lyon 1949). Berl saddles are aluminum oxide $\left(\mathrm{Al}_{2} \mathrm{O}_{3}\right)$ support media that served as packing material for the reactive silver component of the adsorbers. Berl saddles were traditionally coated with $\mathrm{AgNO}_{3}$ within the separation facility. Upon column breakthrough, the saddles were processed to remove iodine (as $\mathrm{AgI}$ ) and were re-used with fresh $\mathrm{AgNO}_{3}$ coating.

Silver-exchanged zeolites have been investigated in Europe, Japan, and the United States for their ability to remove iodine from the off-gas streams arising from nuclear fuel reprocessing. There are multiple types of zeolites, primarily distinguishable by their varying $\mathrm{Si}$ :Al ratios. Silver-exchanged faujasite, commonly designated $\mathrm{AgX}$, is not currently used in a UNF reprocessing facility but has previously been used in both the United States and Italy (Jubin 1988). AgX demonstrates a high capacity for iodine but was eventually discarded in favor of more acid-resistant materials.

Where possible, references for the values or judgements contained within the case study are provided. In some cases, general knowledge is included in the table without citations. In other cases, values were not easily obtained during the course of this study and are designated as unavailable. This does not mean that the metric value has never been measured, but only that our study did not find a reliable source for that particular metric. 
Performance Criteria for Capture and/or Immobilization Technologies

Table 5-1. Metrics for technical performance and physical and chemical characteristics criterion for selected iodine sorbent comparison

\begin{tabular}{|c|c|c|c|c|c|}
\hline Property & Unit & Desired trend & $\begin{array}{c}\mathrm{AgNO}_{3} \text {-coated Berl } \\
\text { saddles }\end{array}$ & Ag-faujasite & Comments \\
\hline Capacity & Moles $/ \mathrm{m}^{3}$ & High & $12.6^{a}$ & $600-2,000^{b}$ & $\begin{array}{l}a(\text { McNabney and Lyon 1949) } \\
b^{b} \text { Katoh 2011) } \\
\text { Up to } 30 \% \text { silver utilization in Ag-saddles; up } \\
\text { to } 100 \% \text { in in zeolites }\end{array}$ \\
\hline Selectivity & $\begin{array}{c}\left(\mathrm{X}_{\mathrm{a}} / \mathrm{Y}_{\mathrm{a}}\right) /\left(\mathrm{X}_{\mathrm{b}} / \mathrm{Y}_{\mathrm{b}}\right) \\
\text { (unitless) } \\
\\
\text { Where } X_{a} \text { and } X_{b} \text { are } \\
\text { mol fractions of } \\
\text { species } \text { a and } b, \\
\text { respectively, in the } \\
\text { adsorbed phase, and } \\
Y_{a} \text { and } Y_{b} \text { are mol } \\
\text { fractions of species a } \\
\text { and } b \text { in the bulk phase }\end{array}$ & High & Good & Good & $\begin{array}{l}\text { Ag-sorbents highly selective for iodine, with } \\
\text { some tramp halogens }\end{array}$ \\
\hline Particle density & $\mathrm{kg} / \mathrm{m}^{3}$ & High & $\mathrm{n} / \mathrm{a}$ & $700-1,000$ & $\begin{array}{l}\text { Commercially available sodium form is } \\
673 \mathrm{~kg} / \mathrm{m}^{3} \text {; density will increase with silver } \\
\text { exchange }\end{array}$ \\
\hline Surface area & $\mathrm{m}^{2} / \mathrm{g}$ & High & Unavailable & Unavailable & \\
\hline Specific heat capacity & $\mathrm{J} /(\mathrm{K} \cdot \mathrm{kg})$ or $\mathrm{J} /\left(\mathrm{K} \cdot \mathrm{m}^{3}\right)$ & $\begin{array}{c}\text { Application } \\
\text { dependent }\end{array}$ & See note & Unavailable & $\begin{array}{l}\text { While } \mathrm{AgNO}_{3} \text { heat capacity is high, the heat } \\
\text { capacity of Berl saddles is low }\end{array}$ \\
\hline Thermal conductivity & $\mathrm{W} /(\mathrm{m} \cdot \mathrm{K})$ & High & Unavailable & Unavailable & - \\
\hline Radiation stability & $\begin{array}{c}\% \text { degradation in } \\
\text { capacity over time as a } \\
\text { function of radiation } \\
\text { exposure }\end{array}$ & $\begin{array}{l}\text { High stability; } \\
\text { low degradation } \\
\text { over time }\end{array}$ & Very good & Good & $\begin{array}{l}\mathrm{AgNO}_{3} \text { refreshed upon saddle column } \\
\text { breakthrough; degradation minimal within the } \\
\text { time it is expected to remain online. } \\
\text { Zeolites are relatively stable in the presence of } \\
\text { radiation. }\end{array}$ \\
\hline Mechanical stability & $\begin{array}{c}\text { Generated fines } \\
<420 \mu \mathrm{m} \text { with losses } \\
\text { to the off-gas stream } \\
\text { of }<50 \mu \mathrm{g} / \mathrm{m}^{3}\end{array}$ & $\begin{array}{l}\text { High stability; } \\
\text { low fines } \\
\text { generation }\end{array}$ & $\begin{array}{l}\text { Very good, but actual } \\
\text { values unavailable }\end{array}$ & $\operatorname{Good}^{c}$ & ${ }^{c}$ Puppe and Wilhelm 1990 \\
\hline
\end{tabular}


Table 5-1. (continued)

\begin{tabular}{|c|c|c|c|c|c|}
\hline Property & Unit & Desired Trend & $\begin{array}{c}\mathrm{AgNO}_{3 \text { _coated Berl }} \\
\text { saddles }\end{array}$ & Ag-faujasite & Comments \\
\hline Thermal stability & $\begin{array}{l}\% \text { degradation in } \\
\text { capacity over time at } \\
\text { selected operating } \\
\text { temperature }\end{array}$ & $\begin{array}{l}\text { High stability; } \\
\text { low degradation } \\
\text { over time }\end{array}$ & High & High & - \\
\hline Chemical stability & $\begin{array}{l}\% \text { degradation over } \\
\text { time as a function of } \\
\text { other species present } \\
\quad \text { in gas stream }\end{array}$ & $\begin{array}{l}\text { High stability; } \\
\text { low degradation } \\
\text { over time }\end{array}$ & High stability & $\begin{array}{l}\text { Degrades in acid and } \\
\text { high humidity }^{d}\end{array}$ & ${ }^{d}$ Jubin1981 \\
\hline Reactivity & $\begin{array}{l}\text { Compatibility as } \\
\text { determined by } \\
\text { standardized } \\
\text { compatibility tables }\end{array}$ & $\begin{array}{l}\text { Demonstrated } \\
\text { compatibility } \\
\text { with all } \\
\text { components of } \\
\text { gas stream and } \\
\text { materials of } \\
\text { construction }\end{array}$ & Compatible $^{e}$ & $\begin{array}{l}\text { Faujasite may not be } \\
\text { acid resistant }^{d}\end{array}$ & $\begin{array}{l}{ }^{d} \text { Jubin } 1981 \\
{ }^{e}(\text { Heeb 1994; Cederberg et. al. 1961; O'Brien } \\
\text { et. al. 1963; Paas et. al. 1951; McNabney and } \\
\text { Lyon 1949) }\end{array}$ \\
\hline
\end{tabular}


Performance Criteria for Capture and/or Immobilization Technologies

Table 5-2. Metrics for technical practicality criterion for selected iodine sorbent comparison

\begin{tabular}{|c|c|c|c|c|c|}
\hline Property & Value & Desired trend & $\begin{array}{c}\mathrm{AgNO}_{3} \text {-coated Berl } \\
\text { saddles }\end{array}$ & Ag-faujasite & Comments \\
\hline Regeneration & $\begin{array}{l}\text { No. of cycles before } \\
\text { degrading to } 80 \% \text { of } \\
\text { capacity for the target } \\
\text { element }\end{array}$ & High & $\mathrm{n} / \mathrm{a}$ & $\mathrm{n} / \mathrm{a}$ & $\begin{array}{l}\text { Ag-based sorbents can be regenerated; but it i } \\
\text { more likely that they would be disposed of as } \\
\text { waste, as the iodine is chemisorbed to the } \\
\text { silver present in the structure, creating the } \\
\text { low-solubility compound AgI }\end{array}$ \\
\hline Co-adsorbed species & Moles/kg & $\begin{array}{l}\text { Small in } \\
\text { number of } \\
\text { species and } \\
\text { quantity }\end{array}$ & $\begin{array}{l}\text { Low, halogens and } \\
\text { antimony as } \mathrm{SbH}_{3} \\
\text { only }\end{array}$ & $\begin{array}{c}\text { Moderate, halogens } \\
\text { and }{ }^{3} \mathrm{HHO}\end{array}$ & $\begin{array}{l}\text { Both Ag-based sorbents will adsorb tramp } \\
\text { halogens }\left(\text { e.g., } \mathrm{F}^{-}, \mathrm{Cl}^{-}\right) \text {; zeolites will also } \\
\text { adsorb }{ }^{3} \mathrm{H} \text { as }{ }^{3} \mathrm{HHO}\end{array}$ \\
\hline Robustness & $\begin{array}{l}\% \text { variation in } \\
\text { operating parameters } \\
\text { tolerated without } \\
\text { deleterious effects }\end{array}$ & High & Medium & Medium & - \\
\hline $\begin{array}{c}\text { Flexibility and } \\
\text { pretreatment }\end{array}$ & $\begin{array}{l}\text { Operating ranges; } \\
\text { no. of unit operations } \\
\text { for pretreatment }\end{array}$ & $\begin{array}{l}\text { High flexibility; } \\
\text { minimal } \\
\text { pretreatment }\end{array}$ & $\begin{array}{l}\text { Some pretreatment } \\
\text { required }\end{array}$ & $\begin{array}{l}\text { Some pretreatment } \\
\text { required }\end{array}$ & $\begin{array}{l}\text { Saddle columns must be heated to avoid } \\
\text { condensation from the process off-gas; } \\
\text { faujasite does not tolerate humidity well. }\end{array}$ \\
\hline Process complexity & $\begin{array}{l}\text { Number and type of } \\
\text { control systems and } \\
\text { unit operations } \\
\text { required }\end{array}$ & Low & High & Low & $\begin{array}{l}\text { For Ag-saddles, upon breakthrough, the } \\
\text { column is shut down, sodium thiosulfate is } \\
\text { used to remove the AgI, the Ag is either } \\
\text { recycled or sent to waste (the usual choice), } \\
\text { the saddles are heated and dried, fresh } \mathrm{AgNO}_{3} \\
\text { is added to coat the saddles, and the column is } \\
\text { dried } \\
\text { No markedly complex operations for Ag- } \\
\text { faujasite }\end{array}$ \\
\hline Energy consumption & $\mathrm{kW} / \mathrm{mol}$ & Low & Unavailable & Unavailable & - \\
\hline $\begin{array}{l}\text { Environmental safety } \\
\text { and health }\end{array}$ & $\begin{array}{l}\text { Classification } \\
\text { according to National } \\
\text { Fire Protection } \\
\text { Association (NFPA) } \\
\text { ratings }\end{array}$ & Low & Good & Good & $\begin{array}{l}\text { Both sorbents have NFPA health ratings of } 2 \\
\text { and are considered Resource Conservation and } \\
\text { Recovery Act waste }\end{array}$ \\
\hline
\end{tabular}


Performance Criteria for Capture and/or Immobilization Technologies

Table 5-3. Metrics for system design and performance criterion for selected iodine sorbent comparison

\begin{tabular}{|c|c|c|c|c|l|}
\hline Property & Value & Desired trend & $\begin{array}{c}\text { AgNO _ coated Berl } \\
\text { saddles }\end{array}$ & Ag-faujasite & Comments \\
\hline Pressure drop & $\mathrm{Pa} / \mathrm{m}$ & Low & Unavailable & Unavailable & $\begin{array}{l}\text { Pressure drop for both is expected to be } \\
\text { relatively low. Ag-faujasite may have slightly } \\
\text { higher pressure drop because of smaller } \\
\text { particles and bed packing. Berl saddles were } \\
\text { used routinely in the Purex Plant at Hanford } \\
\text { (McNabney and Lyon 1949; Cederberg and } \\
\text { MacQueen 1961), implying acceptable } \\
\text { pressure drops }\end{array}$ \\
\hline $\begin{array}{c}\text { Decontamination } \\
\text { factor (DF) }\end{array}$ & $\begin{array}{c}{[\text { Isotope }]_{a} /[\text { [Isotope }]_{b}} \\
\text { Unitless) }\end{array}$ & High & $25-200$ & $>1,000$ & $\begin{array}{l}\text { For Berl saddles, reference Cederberg et. al. } \\
1961 ; \text { McNabney and Lyon 1949; and Moore } \\
1984 . \\
\text { For Ag faujasite reference Thomas et al. 1978 } \\
\text { and Jubin 1981 }\end{array}$ \\
\hline Bed volume & & & & $\begin{array}{l}\text { See McNabney and Lyon 1949 for volume of } \\
\text { Berl saddle column }\end{array}$ \\
\hline
\end{tabular}


Performance Criteria for Capture and/or Immobilization Technologies

Table 5-4. Metrics for technical maturity criterion for selected iodine sorbent comparison

\begin{tabular}{|c|c|c|c|c|c|}
\hline Property & Value & Desired trend & $\begin{array}{c}\mathrm{AgNO}_{3} \text {-coated Berl } \\
\text { saddles }\end{array}$ & Ag-faujasite & Comments \\
\hline $\begin{array}{l}\text { Technology readiness } \\
\text { level of sorbent } \\
\text { system }\end{array}$ & $1-9$ & High & 9 & $6-7$ & $\begin{array}{l}\mathrm{AgNO}_{3} \text {-coated ceramic saddles have been } \\
\text { used in reprocessing facilities (Wershofen and } \\
\text { Aumann 1989). Testing has been done on Ag- } \\
\text { faujasite (Thomas et. al. 1978) }\end{array}$ \\
\hline $\begin{array}{l}\text { Commercial } \\
\text { availability }\end{array}$ & Yes / No & $\begin{array}{l}\text { Readily } \\
\text { available }\end{array}$ & Yes & No & $\begin{array}{l}\text { Ag-saddles are manufactured in place and the } \\
\text { precursor materials are available } \\
\text { Sodium faujasite is commercially available }\end{array}$ \\
\hline $\begin{array}{c}\text { Time to } \\
\text { commercialization }\end{array}$ & $\mathrm{y}$ & Short & None & Very short & $\begin{array}{l}\text { Ag-faujasite can easily become commercially } \\
\text { available, and all other required materials and } \\
\text { unit operations are available and well- } \\
\text { developed }\end{array}$ \\
\hline
\end{tabular}


Table 5-5. Metrics for cost criterion for selected iodine sorbent comparison

\begin{tabular}{|c|c|c|c|c|c|}
\hline Property & Value & $\begin{array}{c}\text { Desired } \\
\text { trend }\end{array}$ & $\begin{array}{c}\mathrm{AgNO}_{3-} \\
\text { coated Berl } \\
\text { saddles } \\
\end{array}$ & Ag-faujasite & Comments \\
\hline $\begin{array}{c}\text { Cost of sorbent } \\
\text { material }\end{array}$ & $\$ / \mathrm{kg}, \$ / \mathrm{Ci}$, or $\$ /$ mole & Low & Moderate & Moderate & $\begin{array}{l}\text { Both sodium-exchanged faujasite and the } \\
\text { saddles (or any other } \mathrm{Al}_{2} \mathrm{O}_{3} \text { support } \\
\text { media) are readily available and } \\
\text { inexpensive } \\
\mathrm{AgNO}_{3} \text { is the cost-driving chemical } \\
\mathrm{AgNO}_{3} \text { can be used to produce silver- } \\
\text { exchanged faujasite, if it is not purchased } \\
\text { commercially) }\end{array}$ \\
\hline Operating cost & $\$ / \mathrm{Ci}$ & Low & Moderate & Low & $\begin{array}{l}\text { There are several unit operations that drive } \\
\text { up the cost of saddle operation: } \\
\text { regeneration involves taking the bed off- } \\
\text { line, washing, dissolving the } \mathrm{AgI} \text { in a } \\
\text { solution of } \mathrm{Na}_{2} \mathrm{~S}_{2} \mathrm{O}_{3} \text {, oxidizing the } \mathrm{I}^{-} \text {to } \mathrm{I}_{2} \text {, } \\
\text { extracting the } \mathrm{I}_{2} \text {, reclaiming the } \mathrm{Ag} \text {, and } \\
\text { reloading the support media. (Heeb 1994; } \\
\text { McNabney and Lyon 1949; Moore 1984; } \\
\text { Vignau et al. 1991; Warren 1961) } \\
\text { Silver-exchanged faujasite is cost-effective } \\
\text { and requires limited unit operations }\end{array}$ \\
\hline
\end{tabular}


The metrics, values, and comments provided in Tables 5-1 through 5-5 reveal several important trends. First, not all metrics will apply to any given sorbent system. An example of this would be the regeneration metric, which is not of interest for either AgNO3-coated Berl saddles or for silver-exchanged faujasite.

Second, if sorbent systems are markedly different, the values provided by the metrics may be disparate on first inspection and should be carefully interpreted in the context of the specific technologies being evaluated. This is illustrated in the capacity metric for the case study, where the capacity (provided in $\mathrm{mol} / \mathrm{m} 3$ ) is notably higher for silver-exchanged faujasite. In this instance, the capacity information should be reviewed in concert with other metrics such as density.

Third, the use of general process knowledge or subjective rankings was often required to complete the case study. This is illustrated by the thermal stability metric, where both technologies were designated "good." Ideally, a more quantitative analysis would be made, but such data were not available. This was a recurring theme in the completion of this case study; it shows that the performance criteria can be used not only for down-selection between two technologies but also can aid in identifying the knowledge gaps (and their associated importance) that should be resolved over the course of a sorbent or waste form development process.

To conclude the case study, the Berl saddles demonstrated promising technical characteristics in multiple categories that were considered of "high" importance, such as thermal, chemical, and radiation stability. However, the technical practicality metric of process complexity (also of high importance) was scored poorly for Berl saddles. Silver-exchanged faujasite possesses high iodine capacity and is of low process complexity, but is less chemically stable than $\mathrm{AgNO}_{3}$-coated Berl saddles. In making a final selection between these two technologies, the factors that are most important for specific plant design should be revisited to complete a determination of the optimal technology.

\section{SUMMARY AND CONCLUSIONS}

In the course of compiling these criteria and associated metric sets, a number of observations were made. First, the use of the tables in this document should include the following considerations:

(1) The tables, as presented, do not weight the importance of one criterion against another. Different users could have different perspectives regarding the relative importance of each criterion.

(2) The tables also do not weigh the relative importance of individual metrics associated with a given criterion.

(3) Some specific metrics may not be applicable for comparison if the capture or waste form technologies being compared differ substantially (for example, comparing the density of a wet scrubber system with that of a solid sorbent is not very informative).

Second, it is important to recognize that some of the metrics listed may be interrelated in complex ways. For example, waste loading and waste density both impact total waste volume, and high density could compensate for low waste loading ( $\mathrm{mol} / \mathrm{kg}$ ). This type of relationship should be acknowledged in comparing sorbent systems or waste form technologies.

One of the more complex aspects of this effort to identify the key criteria and metrics is that, as in many engineering problems, there is not a single answer; and some of the important metrics are actually a function of the system design and not an intrinsic property of the material. It is important when using these metrics to use values from properly designed systems.

Third, in the completion of the case study for silver-based iodine sorbents, it was observed that quantitative data were not available for many of the performance metrics identified in Section 3 (or Section 4). This leads to the important point that some data gaps remain, and these gaps should be addressed in the sorbent or waste form development process. At all points of the research and 
development process, the importance of a metric can be used to identify research priorities for each sorbent or waste form. Additionally, down-selection of sorbents or waste forms is likely to occur at multiple levels of development, and it is expected that these performance metrics could contribute positively to that determination.

In conclusion, thorough lists of performance criteria and associated metrics have been developed for sorbent and waste form evaluation. These criteria address physical, radiological, and chemical characteristics; technical practicality; technical maturity; cost; and, for sorbents, system performance. The sets of criteria and associated metrics appear to be sufficiently robust and should be applicable whether the wastes containing the four volatile radionuclides $\left({ }^{3} \mathrm{H},{ }^{14} \mathrm{C},{ }^{85} \mathrm{Kr}\right.$, and $\left.{ }^{129} \mathrm{I}\right)$ are ultimately classified as low-level or high-level waste. Further, they appear to be sufficient to address both aqueous reprocessing and electrochemical reprocessing of UNF.

These sets of criteria and associated metrics can serve as tools to evaluate performance at multiple stages within the research and development process. It is expected that the evaluation of these criteria and metrics will provide a technically based foundation for the comparison of sorbent and waste form performance for the four volatile radionuclides likely to require capture in a US nuclear fuel reprocessing facility.

Over time, it is expected that additional granularity with regard to the acceptable values will be developed and included in revisions of this document. 


\section{BIBLIOGRAPHY}

Cederberg, GK and DK MacQueen. 1961. Containment of Iodine-131 Released by the RaLa Process. Report No. IDO-14566, Phillips Petroleum Company, Atomic Energy Division, Idaho Falls, ID.

Christensen, AB, JAD Debbio, DA Knecht, and JE Tanner. 1982. "Immobilization and Leakage of Krypton Encapsulated in Zeolite or Glass.” Materials Research Society Symposia Proceedings 6:525-32.

Christensen, AB, JA Del Debbio, DA Knecht, JE Tanner, and SC Cossel. 1983. Immobilization of Krypton-85 in Zeolite 5A. In Proceedings of the 17th DOE Nuclear Air Cleaning Conference (CONF820833), 333-56 pp. The Harvard Air Cleaning Laboratory, Cambridge, MA.

DoD. 2011. Technology Readiness Assessment (TRA) Guidance. Report, US Department of Defense, Washington, DC.

DOE. 2012. Waste Acceptance Product Specifications (Waps) for Vitrified High-Level Waste Forms. Report No. DOE/EM-0093 (Revision 03), US Department of Energy, Washington, DC.

EPA. 2010. Protection of Environment: Chapter I-Environmental Protection Agency (Continued). Part 190_Environmental Radiation Protection Standards for Nuclear Power Operations. 40CFR190.10. US Environmental Protection Agency, Washington, DC.

Heeb, CM. 1994. Radionuclide Releases to the Atmosphere from Hanford Operations, 1944-1972. Report No. PNWD-2222-HEDR, Pacific Northwest Laboratories, Richland, WA.

Jubin, R. T., 1981, Organic Iodine Removal from Simulated Dissolver Off-gas Systems Utilizing SilverExchanged Mordenite. Presented at 74 Annual AIChE Meeting, New Orleans, LA, CONF-811108-14, Oak Ridge National Laboratory, Oak Ridge, TN. http:/www.osti.gov/scitech/servlets/purl/5601265.

Jubin, R.T., 1988, Airborne Waste Management Technology Applicable for Use in Reprocessing Plants for Control of Iodine and Other Off-Gas Constituents, ORNL/TM-10477. Feb 1988. Oak Ridge National Laboratory, Oak Ridge, TN. http://web.ornl.gov/info/reports/1988/3445602722784.pdf.

Jubin, R, N Soelberg, D Strachan, and G Ilas. 2011. Assessments and Options for Removal and Immobilization of Volatile Radionuclides from the Processing of Used Nuclear Fuel. Report No. FCR\&D-SWF-2011-000305, Oak Ridge National Laboratory, Oak Ridge, TN.

Jubin, R, N Soelberg, D Strachan, and G Ilas. 2012a. Fuel Age Impacts on Gaseous Fission Product Capture During Separations. Report No. FCRD-SWF-2012-000089, PNNL-22550, Oak Ridge National Laboratory, Oak Ridge, TN.

Jubin, RT, NR Soelberg, DM Strachan, and G Ilas. 2012b. Position Paper on Practicable Performance Criteria for the Removal Efficiency of Volatile Radionuclides. Report No. FCRD-SWF-2012-000091, Oak Ridge National Laboratory, Oak Ridge, TN.

Jubin, RT, DM Strachan, and NR Soelberg. 2014. Off-Gas Treatment Requirements for Used Nuclear Fuel Processing. Presented at the AIChE Annual Meeting.

Katoh, Yutai, Kevin M. Fox, Hua-Tay Lin, Ilias Belharouak. 2011. Ceramic Materials for Energy Applications: Ceramic Engineering and Science Proceedings, Volume 32, Issue 9, , John Wiley \& Sons, 2011. Pg 23-31.

Kopelevich, DI and H-C Chang. 2001. "Diffusion of Inert Gases in Silica Sodalite: Importance of Lattice Flexibility." Journal of Chemical Physics 115(20):9519-27. 10.1063/1.1414373.

Lim, WT, CH Chang, KJ Jung, and NH Heo. 2001. "Kr Atoms and Their Clustering in Zeolite A." Bulletin of the Korean Chemical Society 22(9):1023-29. 
McNabney, R and AM Lyon. 1949. The Removal of Iodine from Gas Streams by Reaction with Silver in Packed Towers. Report No. ARSC-28 (Del.), Air Reduction Sales Company, Murray Hill, NJ.

Miyake, M, T Konishi, T Suzuki, S Osada, and H Kojima. 1984. "Fixation of Krypton in Type-A Zeolites and Its Leakage Characteristics.” Zeolites 4(3):291-4. 10.1016/0144-2449(84)90041-1.

Moore, EB. 1984. Control Technology for Radioactive Emissions to the Atmosphere at U. S. Department of Energy Facilities. Report No. PNL-4621-Final, Pacific Northwest Laboratory, Richland, WA.

NFPA. 2015. "NFPA 484: Standard for Combustible Metals." National Fire Protection Association, Quincy, MA.

NRC. 2012. Chapter 10, Energy: Part 20-Standards for Protection against Radiation. 10CFR20. US Nuclear Regulatory Commission, Washington, DC.

O’Brien, HA, Jr. and JM Sullivan. 1963. "Process for Recovering Iodine-129." International Journal of Applied Radiation and Isotopes 14(11/12):611-13. 10.1016/0020-708X(63)90045-0.

OSHA. 2005. Combustible Dust in Industry: Preventing and Mitigating the Effects of Fire and Explosion. Report No. Safety and Health Information Bulletin.

Paas, HJ and JK Soldat. 1951. Summary of Measurements for the Activity Density from I-131 for the Period September 1950 to July 1951. Report No. HW-21891, Hanford Works, Richland, WA.

Penzhorn, RD. 1981. "Long-Term Storage of Krypton-85 in Zeolite 5A." Proc. DOE Nucl. Air Clean. Conf. 16(2):1034-46.

Penzhorn, RD and W Mertin. 1984. "Electron Diffraction and X-Ray Investigation of Hydrothermally Vitrified 5 A Zeolite Containing Trapped Gases." J. Solid State Chem. 54(2):235-44. 10.1016/00224596(84)90151-8.

Penzhorn, RD, HE Noppel, A Dorea, K Guenther, H Leitzig, and P Schuster. 1984. Long-Term Storage of ${ }^{85} \mathrm{Kr}$ in Amorphous Zeolite 5A. Report No. PB-85186450 (DE-85701518), Kernforschungszent. Karlsruhe G.m.b.H., Karlsruhe, Germany.

Penzhorn, RD, P Schuster, and HE Noppel. 1982. "Long-Term Storage of Krypton-85 by Fixation in Zeolite 5A.” Eur. Appl. Res. Rep., Nucl. Sci. Technol. Sect. 4(2): 325-412.

Penzhorn, RD, P Schuster, HE Noppel, and LM Hellwig. 1980. Long-Term Storage of Krypton-85 in Zeolites. In Proceedings of the International Symposium on Management of Gaseous Wastes from Nuclear Facilities, 291-300 pp. International Atomic Energy Agency.

Puppe, Lothar, and Jurgen Wilhelm. "Process For The Removal Of Iodine And Organic Iodine Compounds From Gases And Vapors Using Silver-Containing Zeolite Of The Faujasite Type." U.S. Patent 4913850 A, 3 April 1990.

Riley, BJ, JD Vienna, DM Strachan, JS McCloy, and JL Jerden. 2016. "Materials and Processes for the Effective Capture and Immobilization of Radioiodine: A Review." Journal of Nuclear Materials 470:120.

Seoung, D, Y Lee, Y Lee, H Cynn, WJ Evans, C Park, K-Y Choi, DA Blom, T Vogt, and C-C Kao. 2014. "Irreversible Xenon Insertion into a Small-Pore Zeolite at Moderate Pressures and Temperatures." Nature Chemistry 6(9):835-9.

Thomas, T. R., B. A. Staples, and L. P.Murphy. 1978. "The Development of AgZ for Bulk 129I Removal from Nuclear Fuel Reprocessing Plants and PbX for 129I Storage." In Proceedings of the 15th DOE Nuclear Air Cleaning Conference, CONF-780819, p. 394, US Department of Energy, Washington, DC, USA. 
USCSHIB. 2006. Investigation Report: Combustible Dust Hazard Study. Report No. 2006-H-1, US Chemical Safety and Hazard Investigation Board, Washington, DC.

Vignau, B, JP Goumondy, and M Roustan. 1991. Elimination of Iodine from Radioactive Gaseous Effluents in a Packed Column. Report, CEA (France).

Warren, JH. 1961. Control of I-131 Releases to Atmosphere. Report No. HW-68392, General Electric Company, Hanford Atomic Products Operation, Richland, WA.

Wershofen, H. and D. C. Aumann. 1989. "Iodine-129 in the Environment of a Nuclear Fuel Reprocessing Plant: VII. Concentrations and Chemical Forms of 129I and 127I in the Atmosphere," Journal of Environmental Radioactivity, vol. 10, no. 2, pp. 141-156.

Whitmell, DS, L Geens, RD Penzhorn, and MJS Smith. 1987. Capture and Immobilization of Krypton-85. Report No. EUR-10163, Commission of European Communities, Brussels, Belgium. 